Article

\title{
Breaking the Rules: Zodwa Wabantu and Postfeminism in South Africa
}

\author{
Priscilla Boshoff \\ School of Journalism and Media Studies, Rhodes University, 3169 Makhanda, South Africa; E-Mail: p.a.boshofff@ru.ac.za
}

Submitted: 10 November 2020 | Accepted: 20 January 2021 | Published: 23 March 2021

\begin{abstract}
Zodwa Wabantu, a South African celebrity recently made popular by the Daily Sun, a local tabloid newspaper, is notorious as an older working-class woman who fearlessly challenges social norms of feminine respectability and beauty. Her assertion of sexual autonomy and her forays into self-surveillance and body-modification, mediated by the Daily Sun and other tabloid and social media platforms, could be read as a local iteration of a global postfeminist subjectivity. However, the widespread social opprobrium she faces must be accounted for: Using Connell's model of the gender order together with a coloniality frame, I argue that northern critiques of postfeminism omit to consider the forms of patriarchy established by colonialism in southern locales such as South Africa. The local patriarchal gender order, made visible within the tabloid reportage, provides the context within which the meaning of Zodwa Wabanu's contemporary postfeminist identity is constructed. I examine a range of Zodwa Wabantu's (self)representations in Daily Sun and other digital media in the light of this context, and conclude that a close examination of the local gender order assists in understanding the limits of postfeminism's hegemony.
\end{abstract}

\section{Keywords}

coloniality; Daily Sun; gender; postfeminism; South Africa; tabloid

Issue

This article is part of the issue "Gender and Media: Recent Trends in Theory, Methodology and Research Subjects" edited by Sofie Van Bauwel (Ghent University, Belgium) and Tonny Krijnen (Erasmus University Rotterdam, The Netherlands).

(C) 2021 by the author; licensee Cogitatio (Lisbon, Portugal). This article is licensed under a Creative Commons Attribution 4.0 International License (CC BY).

\section{Introduction}

Zodwa Libram 'Wabantu,' the focus of this article, is a minor South African celebrity brought to public attention in 2017 by the popular tabloid newspaper, the Daily Sun. Notorious for refusing to wear underwear when dancing the 'vosho,' a seductive move which she performs at local entertainment venues, Zodwa has faced down the public opprobrium directed at her as an older andto some-unattractive black woman. Instead, successfully creating a media presence around her upwardly mobile lifestyle and audacious confrontation of South Africa's deeply conservative patriarchal norms, she has harnessed her notoriety to 'build her brand,' positioning herself as an autonomous sexual and consumer subject. For these reasons she exemplifies the aspirations of South Africa's upwardly mobile black working class, articulated with the new rights-bearing female subject of the post-apartheid era. If women had been subju- gated during apartheid, the new dispensation endorses a range of rights protected by a famously liberal constitution; in addition, women can now take their place on a world stage by virtue of a globally connected digital media-sphere. Like their international peers, mediasavvy South African women enjoy the pleasures of participation in the online social spaces that affirm the desirable sexual and consumer identities of the day. They achieve visibility and exercise control over how they are represented, and some, like Zodwa, are able to use the media to transform their lives in material ways, undoubted gains which contrast markedly with the country's history of women's oppression.

Appearing to transcend patriarchal demands, and evolving in tandem with a rapidly changing local media culture synced to global media flows, these advances in personal choices and freedoms can readily be associated with the rise of a postfeminist 'sensibility' (Gill, 2007) within the post-apartheid social sphere. Describing a new 
form of femininity identifiable in the neoliberal socioeconomic dispensations that characterise the media-rich, established democracies of the north, postfeminism has been noted for its ability to 'travel' transnationally via the global mediascape, easily inserting itself in southern spaces (Dosekun, 2015). Yet postfeminist scholarship pays scant attention to the patriarchies that it claims to transcend. The aim of this article is to examine the mediation of Zodwa's performances in the light of the local patriarchal gender order-the context within which she is establishing her nascent postfeminist identity-and assess how it might shape the outcomes of the discourse for subjects who take it up. I argue that if (post)feminisms differ, so too are the patriarchies to which they respond: The specificities of the gender order which postfeminism encounters and onto which it is grafted, so to speak, are crucial when evaluating its local appeal and success. To this end, employing a coloniality lens, I provide a brief overview of the historical circumstances that have shaped the current South African gender order.

Additionally, given the close relationship said to exist between postfeminism and the media, the characteristics of the tabloid media which drove Zodwa's rise to social prominence, as well as the local digital divide, inform the analysis. The data for this article is drawn purposively from South African tabloid media between 2017 and early 2020, primarily the Daily Sun newspaper and its Facebook page; the digital entertainment news platform Tshisalive; as well as certain of Zodwa's selfrepresentations and her followers' reactions to these on her public 'blue-ticked' Instagram page, @zodwalibram.

\section{2. "Gender Has a History"}

Postfeminism is a notoriously contradictory, even incoherent, concept (Gamble, 2001). Used indiscriminately by the media, academia and feminists since the late 1990 s, it is deployed to variously celebrate and bemoan a range of feminine identities produced within mediated popular culture. One source of these contradictions is the 'post' of postfeminism, which appears to signal the redundancy of second wave feminist politics. Thus, 'girl power,' for example, is admired for its 'empowered' feminine and sexy assertiveness achieved through consumption, effectively repudiating the stuffy politics-and appearance-of second wave feminists, even while acknowledging their gains (Baumgardner \& Richards, 2000). However, for critics such as Gill (2017) and McRobbie (2004), the emphasis on sexual subjectification, self-surveillance, and the valorisation of choice and individualised empowerment through consumption, are worrying signs of postfeminism's co-option by the global patriarchal neoliberal hegemony and the evisceration of its capacity for feminist critique.

These contrary understandings, roughly sketched above, commonly focus on the cultures of the mediasaturated democracies of the north. But, recognising its circulation within the flows of globalised media, scholar- ship in other spaces draws attention to the translatability of postfeminism's contradictory constellation of orientations, practices and values, and has observed how, as a mediated cultural form, it is not the preserve of the West but is also adopted in marginalised and postcolonial societies (Butler, 2013; Chen, 2012; Lazar, 2006; Switzer, 2013). This scholarship is broadly concerned with the discursive tactics which enable "patriarchy-friendly" (Gill, 2017 , p. 168) postfeminism to insinuate itself successfully into disparate locales, and with the social consequences of its adoption within unequal contexts increasingly defined by the logics of global neoliberalism.

This article, however, avoids these polarising positions, and following Genz and Brabon (2009, p. 5) contends that "postfeminism is context-specific and has to be assessed dynamically in the relationships and tensions between its various manifestations and contexts." In this regard, a sustained examination of the local patriarchal social relations into which global post-feminist discourse is inserted appears indispensable. In much of the scholarship, whether in northern or southern contexts, patriarchy is assumed as largely self-evident. The spectacular style of the young, independent, cosmopolitan women in Dosekun's (2015) study in Nigeria, for example, is constructed as being already outside the purview of local patriarchal relations; through 'empowered' yet normative practices of consumption, sexualisation and selfsurveillance, the hyper-femininity of these elite young women appears to respond to the nebulous patriarchy of global neoliberalism, rather than local patriarchal gender relations. This is in keeping with the northern literature: For example, Gill (2017, p. 608-609), while arguing that "an analysis of gender is central to understanding the current moment...and [its] representation," does not comment on patriarchy as such-rather, it is subsumed beneath a broader set of social concerns, including 'misogyny.'

Given this lacuna, my aim is to locate Zodwa Wabantu's working-class postfeminist performances in the patriarchal gender order that is, I argue, ultimately responsible for their salience within the local milieu. In order to do so, I adopt a coloniality lens compatible with Connell's (1995) model of the gender order. 'Gender order' refers to a hierarchy of masculinities and femininities discursively produced within social institutions, such as the family. Connell proposes that a patriarchal gender order understands male and female as dichotomous: A range of subordinated and complicit masculinities, and variously enabling or resistant femininities, are organised in relation to 'hegemonic' masculinity whose social ascendency is won within a balance of forces. This model explicitly accounts for the multiplicity of masculinities and femininities socially constructed in diverse locales and times, and is particularly cognisant of the gender relations produced within coloniality (Connell, 2009).

As a concept, coloniality describes a longstanding global social and political condition, in that the social, political and economic relations initiated by colonialism 
persist today as 'coloniality' (Maldonado-Torres, 2007; Quijano, 2000). It seeks to understand and confront the "constellation of oppressions" (de Sousa Santos, 2016 , p. 18) of colonialism and its social, political, economic and cultural consequences today. This includes how imperial power "smashed" and remade the gender orders of colonised spaces, and the consequences of this disruption for present-day gender relations (Connell, 2009 , p. 92). Recognising that "gender has a history," Ray $(2018$, p. 86) argues that the task of the scholar interested in gender relations within the postcolony is to develop "a flexible structural analysis that pays attention both to colonial history and to subject formation." No less than physical subjugation, she argues, colonialism depended for its success on the production of new gendered subjectivities: It is the scholar's task to identify the ways in which coloniality continues to produce the gendered subjectivities that serve its interests today.

The British imperial project, the apartheid state and present-day coloniality have all shaped gender relations in South Africa. This transformation has occurred along a number of intersecting fronts, establishing the uneven ground in which contemporary femininities, such as postfeminist ones, take root. The salient elements of this history, presented below, are Christianity and the gender binary, the bifurcation of the state, and a post-transition social milieu characterised by rights, inequality and violence. What emerges is a fractious gender landscape, in which these elements variously combine to produce deeply contested understandings of gender relations.

\subsection{Colonialism, Christianity and the Gender Binary}

From a coloniality perspective, north and south gender relations are mutually constitutive: Gender relations in southern locales are the product of colonialism locally, at the same time that they are tied to the contemporary global 'condition' of coloniality (Ray, 2018; Schiwy, 2007). The concept of a dichotomous heterosexual gender order is itself an artefact of the West's colonising, categorical, hierarchical and binary logic (Amadiume, 1987; Oyewumi, 1997), closely tied to Christianity. In coloniality's schema, "European, bourgeois, colonial, modern man became a subject/agent, fit for rule, for public life... a being of civilisation, heterosexual, Christian, a being of mind and reason" (Lugones, 2010, p. 743). Colonial, bourgeois women supported European men's economic and political enterprises through married domesticity and sexual purity (McClintock, 2002). Christian precepts of monogamous marriage, pre-nuptial sexual chastity, married fidelity, and the centrality of the nuclear family unit, contrast markedly with customary organization of marital and sexual relations (Delius \& Glaser, 2004). Today, most South Africans identify as Christian. Pentecostal churches, many with global ties, as well as African Independent Churches, continue to support individuality alongside patriarchal authority and female submission in line with biblical pre- cepts, including rejection of non-binary gender and sexual identities.

\subsection{The Bifurcation of the State: 'Modernity' and 'Tradition' in Urban and Rural Spaces}

African colonies were constructed around the binary of Western 'modernity' and African 'custom' (Dussel, 2000) and specific forms of identity underpinned the 'bifurcated state' (Mamdani, 1996). Mamdani (1996) argues that for settlers, a modern 'citizen' identity was guaranteed by statutory rights, while a 'subject' identity was assumed of indigenous people bound by a reified customary law to decentralised customary authorities. This bifurcation continues today. Customary law disproportionately affects rural women in particular (Weeks, 2011) with profound implications for women's rights (Claasens, 2009).

Apartheid urban areas in contrast supported 'modern' forms of African patriarchy. Urbanised black South Africans were obliged to live in 'townships,' peri-urban residential areas constructed by the apartheid state with particular forms of 'modern' gender-relations in mind (Robinson, 1996). State housing provided for an idealised patriarchal nuclear family and presumed a household economy centred on the husband's wage-earning capacity and the wife's domesticity (Hunter, 2010). This model of urban gender relations was ultimately impossible to establish in the highly contested township social terrain, inflected as it was by in-migration from rural areas, mines and their associated material and cultural infrastructures, Western media and cultural forms, and struggle politics (Bank, 2011; Morrell, 1998). Today, while elite black South Africans can afford to reside in formerly whites-only suburbs, the majority continue to live in comparatively underserviced townships.

\subsection{Inequality, Rights and Violence}

The 1994 political transition propelled South Africa into the global neoliberal economy, itself the product of coloniality (Quijano, 2000). The structural adjustment that followed precipitated enormous inequality that directly affects gender relations. South Africa is notoriously one of the most unequal countries in the world, and black South Africans suffer high levels of unemployment, which stood at $29.1 \%$ in 2019 . Unemployment has a gendered dimension: $43.5 \%$ of women are unemployed, and young, black urban women with lower education levels in particular suffer from chronic unemployment; in contrast, $35 \%$ of men are unemployed. Today, rather than the apartheid dream of the black urban patri-focal household, young people between the ages of 18 and 34 remain single; and about 37,9\% (approximately 6,1 million) of all households are headed by women alone (Statistics South Africa, 2018, 2020).

It is in this precarious economic environment that rights and violence come to the fore. The rights explicitly given to women by the 1996 Constitution have been 
put into practice unevenly, depending on the context in which the discourse is received. Black women's claims to rights, in particular rights to sexual autonomy, challenge normative gender relations, a confrontation which has not been met without resistance (Posel, 2004). The stubborn patriarchy forged in the course of the long and violent history of colonialism and apartheid still demands a reckoning, all too frequently violent (Gqola, 2015), a sombre counterpoint to postfeminist celebrations of women's emancipation.

A valuable example of how these various elements can combine to shape gender relations in specific locales is provided by Hunter (2010), who carefully examines the evolving post-apartheid gender order in a declining industrial township. He locates his analysis within a neoliberal economy, characterised by profound economic instability and unemployment, which has deprived men of their privileged status as breadwinners. Earlier traditional forms of what he terms 'provider love' were premised on a man's capacity to pay ilobolo (bride price) and maintain a household; today, while this remains an ideal, few men accomplish it. However, material resources remain essential for men to establish sexual relationships with women, and a man's ability as an isoka (playboy) to support a number of sexual relationships has become the yardstick of hegemonic masculinity in this space. Variously complicit with or strategically resistant to this hegemony, women, often unemployed, expect material support for themselves and their children as a normal part of sexual relations. Simultaneously, drawing on a discourse of rights, they claim their freedom to enjoy sexual pleasure and multiple partners as men do, carefully negotiating intimate relationships that bring material benefits. This wins women some independence; but customary and Christian morality (which sanction female chastity) put them at risk of being labelled isifebe (a loose woman) and subject to the violence of men who might try to 'discipline' them. Hunter's work illustrates Connell's (2009, p. 93) claim that within coloniality there is no fixed gender order, but a "reconfigured terrain" on which new struggles take place-including the establishment of discourses such as postfeminism.

\section{The Media Landscape}

Postfeminism is characterised as a "thoroughly mediated" discourse brought to connected elites in southern locales via transnational flows of global media (Dosekun, 2015 , p. 965). Germane to this research is how the discourse is taken up and re-configured by local media for a working-class audience: in this case, tabloid entertainment news. Significantly, Zodwa Wabantu came to public attention in the pages of the Daily Sun, a highly popular national tabloid which addresses black, working class, township residents. Established in 2002 on the back of the demise of the 'quality' white press, it is largely disparaged (Wasserman, 2010); nonetheless, it had, at the time when Zodwa first appears in its reportage in April
2017, the largest readership of any newspaper in South Africa. Daily Sun's Facebook page, and Tshisalive, a digital tabloid platform that regularly reports on Zodwa's activities, are available to anyone with an Internet connection. South Africa enjoys a robust local media infrastructure and is Africa's most 'connected' country. Nevertheless, a marked digital divide means that access to the pleasures and benefits of online platforms follow class and racial lines (Duncan, 2013). Only 36,5 million people out of a population of 59 million currently use the Internet; and of these, only 22 million are active social media users (Johnson, 2021). Instagram - the favoured social media platform for celebrities such as Zodwaaccounted for only $11.85 \%$ of social media use in April 2020 (Statcounter, 2021).

\section{Sample and Method}

The complete coverage of Zodwa in Daily Sun, including readers' letters, its Facebook page and followers' comments, Tshisalive coverage, as well as Zodwa's public Instagram account and her followers' comments, provide the data for this research. From these I purposively select specific 'moments' that best illustrate Zodwa's (self)representation and ambivalent public reception. The moments include her rise to fame, her abortive visit to Zimbabwe, her sexual relationships with younger men, and her body-modification journey. A critical discourse analysis approach (Fairclough, 1995; Richardson, 2007), which recognises the socio-cultural context of textual production and reception, informs the analysis. This consists of a close reading of the texts, paying particular attention to lexicalisation.

\section{Analysis}

\subsection{Zodwa's Rise to Fame}

Zodwa, born in Soweto, grew up exposed to the privations common to township life. Her highly relatable life story, frequently recited in interviews and articles, signifies her heroic transcendence of poverty (Kekana, 2017b). Her fortunes changed in her 30s when "videos of her seductive dancing went viral" and she "became an overnight celebrity." The Daily Sun is the only newspaper to feature her at this decisive turning-point in her career. "ZODWA'S READY TO PARTY IN UK!" exclaims the headline in the SunBuzz section on the inside pages. Already the tropes that will characterise the public response to her meteoric rise to celebrity status are visible: Having no other recognizable talent, she is described simply as a "popular partygoer," whose "behaviour" is decried as setting "a bad example for women." But Zodwa dismisses this criticism: "I don't care what they say," she remarks: "Haters will always hate and I will always shine while they are talking" (Ngcobo, 2017a).

Two months later she reappears, now on page 3, naked: "Zodwa bares all on social media" (Mojalefa, 
2017). She has taken up the Amber Rose challenge, along with several other South Africans who are pictured in a humorous parallel report, "Mzansi gets naked!" The image, taken from Zodwa's Instagram account, shows her from the back as she displays her shapely behind: Daily Sun places an amusingly large yellow star over her bottom. The content of the report, however, is serious, and in true Daily Sun style contrasts markedly with the titillating picture: "I want to spread the message of body positivity as an all-natural woman!" declares Zodwa in the opening line. "I look up" to Amber Rose, she continues, "because, like me, she is always called names for being so confident." Aligned in this way with her famous role model, she extrapolates to the prevalence of genderbased violence. Zodwa describes herself as "upset by the recent rise in killings of women and children" in South Africa. In this context, her self-representation is not frivolous but serious: It "is also a response to violence"; "We are tired of being called whores and being killed for nothing, even when we are fully dressed!" she explains. The report ends with her provocative challenge: "Maybe when we are naked, our voices will be louder."

From these two episodes, and the viral videos of her vosho dance moves, it is already clear that Zodwa's shockappeal for readers lies in her unconventional attitudes and behaviour together with her matter-of-fact personality. A third article seals this effect, capturing her at a prominent social occasion wearing a daring dress that is "slit up to her hip, revealing her tattooed bum and thigh." Her large image, which depicts the long black slit dress and her curvaceous leg, hip and bum, dominates the report: "I wore this because I am proud of my beautiful body," Zodwa declares, and the article ends with an amusing kicker: "She added she was not wearing any panties" (Ngcobo, 2017b). But not everyone is entertained; the letter "Zodwa's outfit sends wrong message" (Nwa-Shavani, 2017) responds to the outcry over her dress and comes down on the side of custom, declaring that "as Africans, ethics and consideration should be taken into account": "This woman doesn't respect herself," continues the writer, worried that Zodwa sets a "poor example" to young people; they should rather "follow celebrities who have strong moral conduct." Indeed, he warns: "Men are [only] polite to women who conduct themselves respectfully." The implicit argument is, of course, that we must not be surprised if men disrespect women who are not respectably dressed, a veiled reference to the tide of gender-based violence that engulfs the country. The letter ends with a stern and patronising admonition: "As women, it is your responsibility to display a positive image in your communities and homes."

\subsection{Confronting Custom}

Soon after her Durban July debut, Zodwa is invited to perform in the neighbouring country of Zimbabwe, at the Harare International Carnival. But the Daily Sun reports that she is disappointed, for the condition for her appearance is that she "must change her show" (Molobi, 2017a). In short, "they require her to wear underwear." The Tourism Authority, responsible for the show's organisation, states its case in the report, which is argued on the ground of custom: The "chiefs and traditional leaders" who attend the performance will apparently "be upset" if they see her without her "panties" on. Zodwa is depicted as outraged: She "fumed" at the news and "lashed out" at the Tourism Authority, which she called "out of line": "What are they to change me?" she demands rhetorically.

The furore provokes even the Zimbabwean President, Robert Mugabe, to weigh in on the topic at a political rally. He renounces her and in so doing reveals how feminine respectability is policed within customary patriarchy. Using this public forum, he "lambasted" Zodwa (Ndaba, 2017), attacking her morals and her lack of respectability: "You just come without covering your decency" he remarks disgustedly, asking: "What do you want? Men to see you?" If it is, "We don't want such," he declares, simultaneously apologising to men for the ban- "I'm sorry we disappointed many men"and acknowledging he is a "killjoy." But his decision is firm: "We don't want an intransigent or stubborn naked nobody coming to cause problems" (Molobi, 2017c). Zodwa contemptuously dismisses the fiasco, and describing herself as a "liberated" woman proclaims that "people need to know that they cannot tell us [women] how to live our lives" (Kekana, 2017a).

In effect, Zodwa aligns herself with a modern and 'feminist' perspective that eschews the discourse of custom. She also uses the occasion to challenge conventional Christian morality. As the scandal reaches its zenith, Zodwa is spotted attending church, an occasion that allows her to repudiate the public opinion that she is immoral. Alive to its readers' religious sentiments, Daily Sun gives her ample space to make her case: Using this public forum, she reminds readers that "every human being, including her, needs to have a relationship with God": "Why are people surprised that I go to church?" she asks indignantly, comparing her treatment to that of men who do far worse things than go pantyless: "Killers [and] rapists...pray and go to church-but they're not questioned" (Molobi, 2017b).

\subsection{Zodwa and Her Ben 10}

If custom and morality are scandalised by the idea of Zodwa's 'pantyless' performances, they are outraged by her non-heteronormative choice of partner, for she habitually dates younger men: At the time that she came to public attention at the age of 33, Zodwa was in a relationship with Ntobeko Linda, some 10 years younger than herself. She confesses that this is a conscious strategy which enables her to avoid the power-relations she once experienced in transactional sexual relationships with older men: "I don't want to be controlled and managed [by older men]" she states unequivocally (MacG, 
2020); instead, she declares that she is "after happiness" and "living my best life" (Zeeman, 2018). However, Daily Sun's readers ignore the implicit critique of patriarchy that her choice presents and instead foreground the age difference, seen as taboo by many. Linda is gleefully described by the tabloids as Zodwa's 'Ben 10,' a colloquialism derived from the children's cartoon series, attached to men who date older women. They appear together on the Daily Sun's Facebook page in "ZODWA IS HAPPY WITH HER BEN 10," a post, derived from her public Instagram account, that garnered one thousand two hundred comments (Daily Sun, 2018). The readers' reactions reveal three broad concerns, the first two of which are negatively charged: suspicion as to Ntobeko's motives, and Zodwa's inappropriate age, while the third category presents more nuanced readings of sexual relationships in the local context and positive endorsements.

First, Ntobeko's motives are judged as mercenary. Zodwa preempts this reading of the relationship in the article linked to the post: "I know people think he's with me for the money but no, that man makes me happy," she declares. But commentators contradict her: "That one is really there for...your money my dear," exhorts one, warning Zodwa to "wake-up." Another agrees: "All women say that 'he is not after my money' before Ben 10 milk them and leave them dry." Not only is Ntobeko there simply to "cash in," but his attachment to Zodwa is questioned on the grounds that she is an older woman whose work is contemptible: "No man will commit himself with a woman who show the whole world her punani [vagina]." Ntobeko's commitment thus renders him mad: "He got some mental illness issue?" asks a disbelieving follower.

Zodwa, in contrast, is a gogo [grandmother, an old woman], accused of "eating children," as well as "pedophila," "statutory rape" and "child abuse," for Ntobeko is an "infant," a "boy" who "has not started to shave yet." In contrast to her younger partner's looks, Zodwa's femininity is scathingly called into question, for "it seems like Zodwa is man and pretty boi is wifey here," and Zodwa "looks like she's the one with a dick." To save Ntobeko from Zowa's unnatural femininity, appeals are made to Christian precepts. Arguing that "this is madness a young boy with ugogo," a commentator moralises that "God is very disappointed about what we do in his world": "People like Zodwa," exclaims another outraged reader, are "the ones that causeth God's rage," an opinion endorsed by another which likens her to "rahab the harlot in the bible." Prayer, a familiar solution for Daily Sun readers, is suggested as a remedy: "God deliver this boy," and "Let's pray for this kid. May God rescue you Son."

More nuanced readings refer to the relationship as a personal choice, and reference the local context in which men struggle to access the financial resources necessary to support sexual relationships. In the latter case, the male commentators acknowledge their relative poverty and the attraction of an older woman with financial means: "If shes older than me $\mathrm{n}$ hv money i can giv it to her evn in public" declares one, while another upbraids the critics, pointing out the reality of relationships in township settings: "If u think zodwa is the only one with a ben 10 out there clearly u hvnt lived in the skwata camp (mkhukhu) [squatter camp shacks]." Some readers bravely confess their desire to have a "sugarmama": "Ppl like us PWR [poor] BEN 10's I wish to get one suger mama," one exclaims while others offer to be Zodwa's Ben 10: "Also in need of sugarmama. Inbox me please." One particularly assertive and amusing statement calls out the haters, drawing attention to the fact that Zodwa has money and an energetic young lover, and implying that her critics are simply penniless, sex-starved and jealous:

She is getting a junior fresh hard dick dt never disappoint and money she cant even count nd u busy judging her while $u$ on free mode [free Facebook with reduced functionality] nd last time $u$ had a dick was 2015.

In short, Zodwa should "do wat make you happy nd keep up girl" and ignore the hate: "Age is nothing but a number, if you are happy why worry?"

The fuss dies down, but a year later Zodwa, by now an established figure, publicly proposes to Ntobeko. The Daily Sun could not be more delighted at the entertainment prospect this event offers: "ZODWA TO LOBOLA BEN 10!" proclaims the front-page headline (Ngcobo, 2019c). The opening paragraph describes how Zodwa not only "got down on her bended knee" but also declared that she'll "be the one who will send uncles to pay lobola [bride money] for him!" Provocatively, the subheading declares "Singer plans to send abakhongi" [customarily, the delegation from the groom's family that negotiates the marriage with the bride's father]. If to propose is unconventional, to pay lobola on behalf of a man is scandalous to an extreme degree; but Zodwa defends her decision stoutly. No doubt drawing on her own experiences of township poverty, she tells the Daily Sun that she "knows there are women who take loans and borrow money so their men can pay lobola," and admonishes them for being secretive about it: "Stop giving your men money for lobola and hiding the truth."

The concern with culture is picked up by a "Cultural expert" (Ngcobo, 2019d) who weighs in on the matter: "What they're doing is against tradition." Horrified that a woman will "lobola a man" - "It is shocking!"- he warns that "their ancestors will turn their backs on them and cause trouble in their marriage." Zodwa remarkably "laughs off" the threat and dismisses tradition out of hand: While she "respects people who do rituals" she herself "doesn't believe in tradition." Even more shocking is that "according to her, she doesn't have ancestors": "If a person is dead, they're dead," she asserts, adding that "I don't even use muthi [witchcraft]." Indeed, "culture has nothing to do with us." She is, in effect, aligning herself with a modern, individualist and Christian 
outlook that eschews custom: "I pray and do things my way."

\subsection{Dear Body: A (Post)Feminist Journey}

Zodwa's unconventional behaviour and attitudes are matched by her unconventional physical appearance: As a mature woman, Zodwa does not fulfil normative expectations of celebrity beauty. Nonetheless, her distinctive physicality is the basis of her public appeal and success. She is noted for her broad, plain, but characterful face, her short, 'unkept' natural hair, and her strong, shapely legs and bum which she employs to such captivating erotic effect in the vosho, her signature dance move. Following the Zimbabwe fiasco, and under pressure as she becomes more visible as a media personality, Zodwa gives up her "pantyless" performances and promises to "tone things down" (Mdluli, 2018). Nevertheless, she is under no illusion about the source of her attraction: her bold sexuality and an unshakeable self-confidence. Conscious of the taboos she breaks and the revolutionary example that this sets for others given the patriarchal context in which she operates, she argues that women, whom she describes somewhat dismissively as "domestic beings" - "people who just have to cook and stuff" - were initially hostile until they saw how "free" she is (Kekana, 2017c). Their attitudes are changing: Now they "look at me and think, 'actually, Zodwa may be right.' Why should I compromise on living my best life because of a man?" Extending this logic, she declares that "guys don't like me" for the same reasons: "They say I'm making women more 'aware' of their freedom." She motivates women to "stop being used by men" (Mdluli \& Silangwe, 2018); "Ladies, you have the power and you must use it," she urges them: "Take it from me. I am using my punani to make R35 000." The trick, she emphasises, is to "be yourself."

But this advice must compete with harsh criticism. Zodwa's age, her homely face, and the way she uses her body to make money are frequently ridiculed. Indeed, "I'm told every day that I'm old and ugly," she observes (Mdluli, 2018). Remarkably, this severe commentary does not inhibit a frank and unashamed self-evaluation which Zodwa doesn't hesitate to share publicly: "I love myself the way I am and will continue to embrace the beautiful body God gave me," she asserts defiantly (Molobi, 2018), adding that she refuses to be "pressurised into imitating other celebrities." An early Instagram photograph displays her behind as she straddles a sun-recliner wearing a thong bikini: "Show me a Woman without Cellulite" reads her caption, along with laughing and peach emojis, "Being a Woman, Humble" (Libram, 2017). It is precisely this unabashed and level self-appraisal, by which she consciously identifies with ordinary people, that wins her fans' loyalty: As one follower remarks: "This is who we are!!! Real $\$$ thank you @zodwalibram," while reminding others of the real risks that Zodwa takes, for she is "putting it out there for those of us who are proud but can't quite share on such platforms for various reasons."

In time, however, as her fame, income and endorsement opportunities grow, Zodwa begins to make different kinds of decisions about her appearance. The first indication of dissatisfaction with her body is seen in the 2018 Marie Claire naked issue, in which she apologises to her body for negative feelings: “\#DearBody, I'm sorry for the times I've hated you, especially the face," simultaneously acknowledging what her body has achieved for her: "You're good to me-I mean it" (Libram, 2018a). While she had initially emphatically declared that she "owe[s] no one an explanation for [her] cellulite and wrinkles," and that she "will not change for anyone" (Luhanga \& Tlhoaele, 2018), she begins-notably, after her separation from Ntobeko Linda-to experiment with cosmetic body treatments and modifications, becoming in the process an 'influencer' for the clinic that she patronises.

She shares these experiences in a forthright and humorous manner on Instagram, beginning innocuously enough with a "health check" (Libram, 2018b). Soon, they extend to more radical interventions: "Vampire" facials, botox treatments and breast augmentations. But most astonishing is the video of her first "vaginal rejuvenation," which is viewed by 191,665 followers (Libram, 2019). The video shows the doctor and nurse in blue scrubs as they conduct the procedure. Zodwa, lying with her legs bent and positioned away from the viewer, discusses how the vagina changes after giving birth and the impact this has on sexual pleasure. Followers' comments reveal a range of positions taken in response to her frank disclosure, informed by the discourses available to them. Unsurprisingly, given South Africa's patriarchal hegemony, many are openly misogynistic: "Is ben $10 \mathrm{com}$ plaining?" reads one of the more innocuous rhetorical questions which target Zodwa's sexual history. However, haters are disciplined by readers who call out their ignorance: "If we don't know something we tend to judge than to learn...stop being stubborn and take time to learn about things." Some try to educate uninformed followers. Lessons are given about customary precedents for vaginal tightening: "This is sometng was done before our for fathers [forefathers] nd it was done by sangomaz [traditional healers]," as well as suggestions for practical and less expensive home remedies: "Cleanse it daily with cold water sis [sister], why you wasting your money." Also frequent are expressions of thanks and approval: "Vaginal tightening is a greatest gift to your man," and "I didn't know that it can be tightened. Thank you @zodwalibram for educating me." Others delightedly acknowledge Zodwa's frank revelation where most would be too embarrassed: "Jooooooh [colloquial expression of amazement] I salut you!!!! Most of the girls hide tht they did this!! but u not ashamed jst tel show d world!!! 通." Indeed, Zodwa in this respect also outshines other celebrities: "Most celebrities are afraid to comment here....Lead them zondwa we love you." So, while many are shocked ("I am speechless," "Please Jesus 
you take so long to come and fetch us") the undercurrent is one of amused appreciation: "Tighten it wena Zodwa wethu [you are our only Zodwa] it's urs \& U are Ours 9.

\section{Conclusion}

This article proposes that in order to understand postfeminism in southern spaces we need to situate the discourse within the gender relations forged by colonialism and its aftermath. While postfeminism is compatible with global neoliberalism, local gender discourses also contend with postfeminism to shape the gender relations deemed appropriate for this context. The contestation plays out unpredictably. In this unequal southern space, what it means-and what it takes-for an older, working-class and less attractive woman like Zodwa to enact an assertive sexuality, or to 'discipline' her unruly female body, is not self-evident. The article suggests that global postfeminism loses its hegemony as 'common sense' (Gill, 2017) as it is reworked, with sometimes surprising results, by the pressures of gender relations within coloniality. In the South African case, these are characterised by a gender binary linked to Christian morality, the solidification of customary identities, and a 'modern' urban patriarchy exercised in a social context marked by inequality, rights and violence.

Religious and customary mores, a product of coloniality, retain a significant hold over hetero-patriarchal gender relations in which women are constructed as ideally obedient, chaste and respectful. Zodwa uncompromisingly refuses to observe these social dictates, and must fiercely defend herself against criticism from both camps. Zodwa identifies as a Christian; but this self-identification must contend with accusations that her 'naked' performances and non-conforming relationship choices are immoral and ungodly. Zodwa also rejects aspects of custom that would have her submit to men's authority. She distinguishes herself from women who willingly submit to customary patriarchal expectations ("domestic beings") and encourages them to follow her example to recoup their power. The tabloid coverage consciously juxtaposes custom with Zodwa's unconventionality, provoking readers to evaluate the direct assault on patriarchal authority signified by her attitudes and behaviours. But if custom is deferred to by readers and commentators, the frequent coverage of Zodwa's nonconforming femininity by the tabloid press in effect endorses her modern and independent identity as noteworthy.

Zodwa's postfeminist performances are also framed by the harsh inequality produced by national and global neoliberalism, itself the product of coloniality. Inequality directly shapes gender relations in township settings where scarce financial resources provide access to the sexual economy. If Zodwa used transactional sex with older men to survive in early womanhood, as a mature woman she consciously places herself beyond their control. Instead, from a position of social and financial power, she strategically chooses a younger lover who lacks the authority that comes with age. Yet, while this enables her to avoid a direct confrontation with patriarchal demands in the relationship itself, she cannot entirely escape heteronormative censure, which refers to Christian and customary morality to discipline her unruly sexuality. It also chastises and protects the subordinated masculinity of her lover to recoup it for 'normal' heterosexual relations.

Similarly, Zodwa's surgical makeovers, which in northern contexts signify women's ultimate inscription as postfeminist subjects (Heller, 2007), acquire meanings that go beyond the disciplinary rigors of postfeminist discursive practice. Instead, they signify Zodwa's usurping of patriarchal control over the female body which she refashions for her own pleasure. That this is heterosexual but not heteronormative pleasure renders it all the more outrageous to those whose normative prescriptions she confronts. Interestingly, it is the women followers on Instagram who look to her as a role model of modern and liberated womanhood who appear most moderate and encouraging-perhaps unsurprisingly, for they are likely younger, more well-to-do (affording social media participation) and globally oriented.

Zodwa justifies her uninhibited enjoyment of sex and her profit-oriented deployment of her sexual appeal by drawing on a potent discourse of rights. In a context where rights remain unrealised for many, her claim to individualised pleasure and sexual choice, as well as her conscious sexual subjectification, appears not 'post' feminist so much as feminism itself, offering a nonconforming example of heterosexual femininity to the women who admire her. If "postfeminism suggests that it is the very success of feminism that produces its irrelevance for contemporary culture" in the north (Tasker \& Negra, 2007, p. 8), in this southern context Zodwa's outrageous performance of postfeminism suggests a form of feminist practice! However, as followers point out, the prevalence of punitive patriarchal violence ensures that Zodwa's individualistic claim to rights remains unavailable yet to many women. If postfeminism reveals the boundaries of patriarchal tolerance, patriarchy sets the limits of what postfeminist discourse can achieve.

\section{Acknowledgments}

The author acknowledges the financial assistance provided by Rhodes University for the Article Processing Fees.

\section{Conflict of Interests}

The author declares no conflict of interests.

\section{References}

Amadiume, I. (1987). Male daughters, female husbands: Gender and sex in an African society. London: Zed Books. 
Bank, L. (2011). Home spaces, street styles: Contesting power and identity in a South African city. London: Pluto.

Baumgardner, J., \& Richards, A. (2000). Manifesta: young women, feminism, and the future. New York, NY: Farrar, Straus and Giroux.

Butler, J. (2013). For white girls only? Post-feminism and the politics of inclusion. Feminist Formations, 25(1), 35-58.

Chen, E. (2012). Shanghai(ed) babies. Feminist Media Studies, 12(2), 214-228.

Claasens, A. (2009). Who told them we want this bill? The traditional courts bill and rural women. Agenda, 23(82), 9-22.

Connell, R. (1995). Masculinities. Cambridge: Polity. Connell, R. (2009). Gender (2nd ed.). Cambridge: Polity.

Daily Sun. (2018, January 23). Zodwa is happy with her Ben 10 [Facebook status update]. Retrieved from https://www.facebook.com/sadailysun/posts/ 1735585343163690

de Sousa Santos, B. (2016). Epistemologies of the South and the future. From the European South, 1, 17-29.

Delius, P., \& Glaser, C. (2004). The myths of polygamy: A history of extra-marital and multi-partnership sex in South Africa. South African Historical Journal, 50(1), 84-114.

Dosekun, S. (2015). For Western girls only? Postfeminism as transnational culture. Feminist Media Studies, 15(6), 960-975.

Duncan, J. (2013). Mobile network society? Affordability and mobile phone usage in Grahamstown East. Communicatio, 39(1), 35-52.

Dussel, E. (2000). Europe, modernity, and Eurocentrism. Nepantla, 1(3), 465-478.

Fairclough, N. (1995). Media discourse. London: Arnold.

Gamble, S. (2001). Postfeminism. In S. Gamble (Ed.), The Routledge companion to feminism and postfeminism (pp. 43-54). London: Routledge.

Genz, S., \& Brabon, B. (2009). Postfeminism. Edinburgh: Edinburgh University Press.

Gill, R. (2007). Post-feminist media culture: Elements of a sensibility. European Journal of Cultural Studies, 10(2), 147-166.

Gill, R. (2017). The affective, cultural and psychic life of postfeminism: A postfeminist sensibility 10 years on. European Journal of Cultural Studies, 20(6), 606-626.

Gqola, P. (2015). Rape: A South African nightmare. Johannesburg: MF Books.

Heller, D. (Ed.). (2007). Makeover television: Reality remodelled. London: I.B. Tauris.

Hunter, M. (2010). Love in the time of Aids. Scottsville: UKZN Press.

Johnson, J. (2021). Digital population in South Africa as of January 2020. Statista. Retrieved from https:// www.statista.com/statistics/685134/south-africadigital-population

Kekana, C. (2017a, August 25). 'I don't promise to compromise' Zodwa Wabantu goes ahead with Zim gig.
Tshisalive. Retrieved from https://www.timeslive. co.za/tshisa-live/tshisa-live/2017-08-25-i-dontpromise-to-compromise--zodwa-wabantu-goesahead-with-zim-gig/

Kekana, C (2017b, October 9). Meet the real Zodwa Wabantu: Mother, pantyless \& taking cash for sex. Tshisalive. Retrieved from https://www.timeslive. co.za/tshisa-live/tshisa-live/2017-10-09-meet-thereal-zodwa-wabantu-mother-pantyless-amp-takingcash-for-sex

Kekana, C. (2017c, October 12). 'It was just curiosity,' says Zodwa Wabantu on hate from women. Tshisalive. Retrieved from https://www.timeslive.co.za/tshisalive/tshisa-live/2017-10-12-it-was-just-curiositysays-zodwa-wabantu-on-hate-from-women

Lazar, M. (2006). "Discover the power of femininity!" Analyzing global "power femininity" in local advertising. Feminist Media Studies, 6(4), 505-517.

Libram, Z. [@zodwalibram]. (2017, August 5). Show me a woman without cellulite [Instagram photo]. Retrieved from https://www.instagram.com/p/ BXaJsHzANKd

Libram, Z. [@zodwalibram]. (2018a, August 20). Dear Body [Instagram photo]. Retrieved from https:// www.instagram.com/p/BmtYR8MBOXX

Libram, Z. [@zodwalibram]. (2018b, October 18). Doing my health check [Instagram photo]. Retrieved from https://www.instagram.com/p/BpFJ7VAhRRv

Libram, Z. [@zodwalibram]. (2019, July 17). Vaginal tightening/vaginal rejuvenation/virgin vagina [Instagram video]. Retrieved from https://www.instagram.com/ p/BOBTCppHyDO

Lugones, M. (2010). Towards a decolonial feminism. Hypatia, 25(4), 742-759.

Luhanga, E., \& Tlhoaele, K. (2018, March 12). Zodwa's rude exit! Daily Sun, p. 3.

MacG. (2020, August 13). Zodwa Wa Bantu on Ben10's, Khanyi Mbau, scandals, childhood, haters. \#Podcastwithmacg. Retrieved from https://www.youtube. com/hashtag/podcastwithmacg

Maldonado-Torres, N. (2007). On the coloniality of being. Cultural Studies, 21(2/3), 240-270.

Mamdani, M. (1996). Citizen and subject: Contemporary Africa and the legacy of late colonialism. Princeton, $\mathrm{NJ}$ : Princeton University Press.

McClintock, A. (2002). Carnal knowledge and imperial power: Race and the intimate in colonial rule. Berkeley, CA: University of California Press.

McRobbie, A. (2004). Notes on postfeminism and popular culture: Bridget Jones and the new gender regime. In A. Harris (Ed.), All About the girl: Culture, power and identity (pp. 3-14). London: Routledge.

Mdluli, Z. (2018, January 9). Zodwa: my aim's to please my fans. Daily Sun, p. 3.

Mdluli, Z., \& Silangwe, M. (2018, January 8). It's D-Day for Zodwa! Daily Sun, p. 3.

Mojalefa, K. (2017, June 13). Zodwa bares all on social media Daily Sun, p. 3. 
Molobi, S. (2017a, August 24). Zodwa's panty fury! Daily Sun, pp. 1-2.

Molobi, S. (2017b, September 13). I need God like everyone else! Daily Sun, p. 3.

Molobi, S. (2017c, December 11). Zodwa's scared to go to Zim. Daily Sun, p. 3.

Molobi, S. (2018, March 19). That's not a dress, Zodwa! Daily Sun, p. 3.

Morrell, R. (1998). Of boys and men: Masculinity and gender in Southern African Studies. Journal of Southern African Studies, 24(4), 605-630.

Ndaba, N. (2017, September 12). Mugabe scolds Zodwa Wabantu and her lack of panties. Tshisalive. Retrieved from https://www.timeslive.co.za/tshisalive/tshisa-live/2017-09-12-mugabe-scolds-zodwawabantu-and-her-lack-of-panties

Ngcobo, M. (2017a, April 4). Zodwa's ready to party in UK! Daily Sun, p. 13.

Ngcobo, M. (2017b, July 3). Tongues wag over Zodwa! Daily Sun, p. 3.

Ngcobo, M. (2019c, May 7). Zodwa to lobola Ben 10! Daily Sun, pp. 1-2.

Ngcobo, M. (2019d, May 29). 'Dead have no power!' Daily Sun, p. 5.

Nwa-Shavani, J. (2017, July 6). Zodwa's outfit sends wrong message. Daily Sun, p. 14.

Oyewumi, O. (1997). The invention of women: Making an African sense of Western gender discourses. Minneapolis, MN: University of Minnesota Press.

Posel, D. (2004). 'Getting the nation talking about sex': Reflections on the discursive constitution of sexuality in South Africa since 1994. Agenda, 18(62), 53-63.

Quijano, A. (2000). Coloniality of power, Eurocentrism, and Latin America. Neplanta, 1(3), 533-580.

Ray, R. (2018). Postcoloniality and the sociology of gender. In J. Messerschmidt, P. Yancey Martin, M. Messner, \& R. Connell (Eds.), Gender reckonings: New social theory and research (pp. 73-89). New York, NY:
New York University Press.

Richardson, J. (2007). Analysing newspapers: An approach from Critical Discourse Analysis. Basingstoke: Palgrave Macmillan.

Robinson, J. B. (1996). The power of apartheid: State, power and space in South African cities. Oxford: Butterworth-Heinemann.

Schiwy, F. (2007). Decolonisation and the question of subjectivity: Gender, race and binary thinking. Cultural Studies, 21(2/3), 271-294.

Statcounter. (2021). Social media stats South Africa. Statcounter Global Stats. Retrieved from https:// gs.statcounter.com/social-media-stats/all/southafrica

Statistics South Africa. (2018). General household survey. Pretoria: Statistics South Africa. Retrieved from http://www.statssa.gov.za/publications/P0318/ P03182018.pdf

Statistics South Africa. (2020). Quarterly labour force survey: Quarter 4: 2019. Pretoria: Statistics South Africa. Retrieved from http://www.statssa.gov.za/ publications/P0211/P02114thQuarter2019.pdf

Switzer, H. (2013). (Post) feminist development fables: The girl effect and the production of sexual subjects. Feminist Theory, 14(3), 345-360.

Tasker, Y., \& Negra, D. (Eds.). (2007). Interrogating postfeminism: Gender and the politics of popular culture. Durham, NC: Duke University Press.

Wasserman, H. (2010). Tabloid journalism in South Africa. Indiana, IN: Indiana University Press.

Weeks, M. (2011). Beyond the traditional courts bill. SA Crime Quarterly, 35, 31-40.

Zeeman, K. (2018, March 9). Zodwa: my Ben 10 is not chowing my money. Tshisalive. Retrieved from https://www.timeslive.co.za/tshisa-live/tshisa-live/ 2018-03-09-zodwa-my-ben-10-is-not-chowing-mymoney

\section{About the Author}

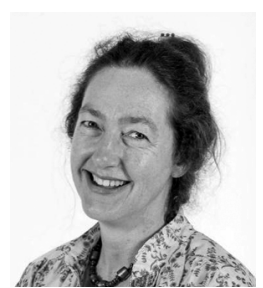

Priscilla Boshoff teaches media and cultural studies at the Rhodes University School of Journalism and Media Studies, South Africa. Much of her research is concerned with the relationship between gender and popular culture in southern contexts, including tabloid newspapers, television and social media. 